Research Article

\title{
The association between demographic and attitude factors with the practice of malaria prevention among the rural community in Purworejo district, Indonesia
}

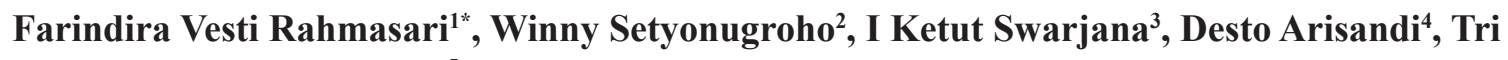 \\ Wulandari Kesetyaningsih ${ }^{5}$ \\ 1,5) Department of Parasitology, School of Medicine, Faculty of Medicine and Health Sciences, Universitas Muhammadiyah \\ Yogyakarta \\ 2) Magister of Hospital Administration, Universitas Muhammadiyah Yogyakarta \\ 3) Institute of Technology and Health Sciences Bali \\ 4) Institute of Health Guna Bangsa, Yogyakarta
}

\begin{tabular}{ll}
\multicolumn{1}{c}{ A R T I C L E } & I N F O \\
\hline Submitted & : July 2020 \\
Accepted & : November 2020 \\
Published & : January 2021
\end{tabular}

Keywords:

Malaria, prevention practice, mosquito net, Indonesia

*Correspondence:

farindira.vesti@gmail.com

\section{ABSTRACT}

Malaria is one of the global health problems that is faced by many countries, including Indonesia. This study aimed to examine the association between demographic and attitude factors with malaria prevention in the rural areas of Purworejo District, Indonesia. A community survey was conducted in Purworejo District that involved 147 respondents by using simple random sampling to select the respondents. A questionnaire interview was used to collect data about demographic factors, attitudes, and malaria prevention practices. A Chi-square test was performed to examine the association between demographic and attitude factors with the practice of malaria prevention in the community. Among 147 respondents, 80 (54.4\%) respondents conducted malaria prevention practice using bed mosquito net in their own houses. Demographic factors such as education level $(\mathrm{p}<0.001)$, occupation $(\mathrm{p}=0.016)$, and attitude factor $(\mathrm{p}=0.006)$ were significantly associated with the use of bed mosquito net for malaria prevention practice. Meanwhile, $63(42.9 \%)$ respondents used ventilation mosquito net for malaria prevention practice. Demographic factors such as education level $(p<0.001)$, age groups $(p=0.005)$, occupation $(p=0.002)$, and attitude factor $(p=0.001)$ were associated significantly with the use of ventilation mosquito net for malaria prevention practice. Overall, malaria prevention by using both bed and ventilation mosquito nets were very low percentages. 


\section{INTRODUCTION}

Malaria is a life-threatening disease caused by parasites transmitted to humans through bites of infected Anopheles female mosquitoes (WHO, 2018). Malaria is spread in 95 countries, and even 3.2 billion people in the world live in the risky area of malaria (WHO, 2016). In 2017, around 219 million malaria cases were reported globally, and in 2018 the number of malaria cases increased to 228 million cases, with $93 \%$ in Africa region and $3,4 \%$ in the South-East Asia region. There were 405,000 deaths due to malaria (WHO, 2019). In Indonesia, the number of Annual Parasite Incidence (API) of malaria was 0.68 per 1000 citizens, and ACT percentage coverage was $97 \%$ in 2018. Malaria cases occurred around the hills, border areas, rivers, and paddy fields in Purworejo District. With a vector density of $0.38-3.85$ mosquitoes/ individuals/hour, the Anopheles species accounts for transmission in 76-88 percent of endemic malaria areas in Purworejo District during the year (Murhandarwati et al., 2015; Mursid, Sudibyakto, Gunawan, Sutomo, \& Windraswara, 2015). Malaria cases have decreased from 2010 to 2014, but the malaria handling program neither lowers the cases in endemic areas nor maintain in the free endemic area (Kementrian Kesehatan RI, 2020). Purworejo District had a previous history of malaria fluctuation cases. Meanwhile, Purworejo can be categorized as a malariaendemic area whose cases have remained throughout the year (Rejeki, Fuad, Widartono, Murhandarwati, \& Kusnanto, 2019). Malaria cases started increasing in 2014 with 567 cases, constantly 720 cases in 2015 and 2017, and reach 720 in 2018 (Dinas Kesehatan Purworejo, 2019).

Indonesia is committed to eliminating malaria in accordance with the $200760^{\text {th }}$ WHO global agreement (Kementrian Kesehatan RI, 2009). Elimination of malaria is very likely because three main keys are available such as availability of Artemisinin Combination Therapy (ACT) drugs; rapid diagnostic techniques with Rapid Diagnostic Test (RDT); and prevention strategies using Long Lasting Insecticide Nets (LLIN) mosquito nets or Impregnated Treated Nets (ITNs), backed by a strong commitment from local government (Kementrian Kesehatan RI, 2017). According to WHO, the most important in preventing malaria is vector control, such as reducing mosquito bites' opportunity to humans. The people living in the high-risk areas of malaria are recommended to use mosquito nets, including bed and ventilation mosquito nets (WHO, 2019). There are currently three types of mosquito net: simple untreated net, Insecticidal Treated Nets (ITNs), and long-lasting insecticide-treated net (LLINs) (Lover, Sutton, Asy, \& WilderSmith, 2011). ITNs are estimated twice times more effective compared to untreated nets and provide more than $70 \%$ protection. These nets are dip-treated using a synthetic pyrethroid insecticide, either deltamethrin or permethrin. ITNs should be re-infused with insecticide every six months for optimum efficacy. This method caused a logistical issue in rural areas. Fresh, long-lasting insecticide nets (LLINs) in most countries replaced the use of ITNs (Bachou, Tylleskär, Kaddu-Mulindwa, \& Tumwine, 2006; Bhatt et al., 2015; Masum et al., 2010). Another study suggests that using a bed net while sleeping might reduce malaria likelihood in Maluku but not in two other locations, namely North Maluku and East Nusa Tenggara (Ipa, Widawati, Laksono, Kusrini, \& Dhewantara, 2020). In some areas, the use of ITNs also seemed less protective, although the use of ITN is considered one of the most cost-effective and preventive malaria strategies. These results are consistent with several studies that suggested unused bed nets (ITNs) treated with insecticide projected an increase in malaria incidence (Asante \& Asenso-Okyere, 2003; Iliyasu, Babashani, Abubakar, Salahudeen, \& 
Aliyu, 2013; Monasch et al., 2004; Pinchoff et al., 2015).

Many efforts have been made in terms of malaria prevention and control. However, they did not focus comprehensively on active involvement and the local community. Therefore, local communities' concerted efforts with their demographic situation are vital in improving the malaria disease control plan. In this sense, it is essential to understand people's views on malaria and to identify specific factors that contribute to fluctuations in transmission and to help develop the best strategy to achieve the goal of malaria eradication. Therefore, research is needed to examine the relationship between demographic factors and attitudes with malaria prevention practices in rural areas of Purworejo District, Indonesia.

\section{METHODS}

A cross-sectional study was conducted in the rural areas of Purworejo District in Central Java Province of Indonesia. There were 147 respondents recruited and involved in this study. The inclusion criteria, including (1) respondents age 5-55 years old with malaria risk (divided into three parts: 1. Socioecological status: gender, age, occupation, and behaviors; 2. Individual-level: lack of knowledge, unimproved housing, mosquito net, mosquito coils, protective clothes, repellent, staying outdoor overnight; 3 . Household-level: number of inhabitants, household condition, availability of mosquito breeding sites around the home, household economic condition, ITNs ownership); (2) respondents with history went to malaria-endemic areas; (3) Willing to participate voluntarily in this study to fulfill informed consent from the respondents or a parent or guardian in the case of children. The exclusion criteria include respondents with malnutrition, respondents with other infections but do not cause by malaria (anamnesis and microscopy examination), pregnant women, and mother who is breastfeeding.

This research protocol was reviewed and approved by The National Ethics Commission (Number: 14035/KEP-UNISA/I/2020). Respondents have provided written approval for their involvement in the study. For this analysis, the respondents' identities have all been removed from the dataset. The research tools that used in this study was a questionnaire that developed by researchers consisting of (1) demographic factors such as age, gender, education level, number of family members, and respondent's occupation; (2) attitude of respondents towards malaria disease and prevention; (3) practice on malaria prevention about using bed and ventilation mosquito nets. Furthermore, data were collected by an interview with the respondents in the community. Before the interview was started, the respondents were explained about this research's objectives and asked them to be involved in this study. In addition, respondents were asked to give a signature before the interview was started. The Chi-square test was performed to examine the association between demographic and attitude factors with the practice of malaria prevention in the community. 


\section{QANUN MEDIKA \\ JURNAL KEDOKTERAN FKUM SURABAYA \\ http://journal.um-surabaya.ac.id/index.php/qanunmedika}

\section{RESULTS}

Among 147 respondents, the majority of them were age 21-60 years old (76,9\%), female $(61.2 \%)$, and the education level was an elementary school (63.9\%). Based on the type of occupation, most participants were engaged in farming (39.5\%). More than
$50 \%$ of the respondents were having 3-4 family members $(57.1 \%)$.

In all areas, most participants included in the study appeared the most good attitude (61.2\%). A large percentage of the participant had attained the use of bed mosquito net $(54.4 \%)$ and not used ventilation mosquito net (57.1\%).

Table 1. Demographic characteristics of respondents in rural areas of Purworejo District, Indonesia $(\mathrm{n}=147)$

\begin{tabular}{lll}
\hline Variables & n & \% \\
\hline Respondent's age (years) & & \\
$<21$ years & 10 & 6.8 \\
21-60 years & 113 & 76.9 \\
$>60$ years & 24 & 16.3 \\
\hline Gender & & \\
Male & 57 & 38.8 \\
Female & 90 & 61.2 \\
\hline Education level & & \\
Elementary school & 94 & 63.9 \\
Junior high school & 40 & 27.2 \\
Senior high school & 11 & 7.5 \\
Higher education & 2 & 1.4 \\
\hline Occupation & & \\
Farmer & 58 & 39.5 \\
Household mother & 44 & 29.9 \\
Employers & 20 & 13.6 \\
Employee & 25 & 17.0 \\
\hline Number of family member & & \\
1-2 family members & 17 & 11.6 \\
3-4 family members & 84 & 57.1 \\
$>4$ family members & 46 & 31.3 \\
\hline
\end{tabular}

Table 2. Attitude and practice of malaria prevention among respondents in rural areas of Purworejo District, Indonesia $(n=147)$

\begin{tabular}{lcc}
\hline Variables & $\mathbf{n}$ & $\mathbf{\%}$ \\
\hline Attitude toward malaria disease & & \\
Good & 90 & 61.2 \\
Poor & 57 & 38.8 \\
\hline Category of using a bed mosquito net & & \\
Use & 80 & 54.4 \\
Not used & 67 & 45.6 \\
\hline Category of using a ventilation mosquito net & & \\
Use & 63 & 42.9 \\
Not used & 84 & 57.1 \\
\hline
\end{tabular}




\section{QANUN MEDIKA}

Table 3. Factors associated with the practice of malaria prevention among respondents in rural areas of Purworejo District, Indonesia $(n=147)$

\begin{tabular}{|c|c|c|c|c|}
\hline \multirow[b]{2}{*}{ Variables } & \multicolumn{2}{|c|}{$\begin{array}{l}\text { Use of bed mosquito } \\
\text { net }\end{array}$} & \multicolumn{2}{|c|}{$\begin{array}{c}\text { Use of ventilation } \\
\text { mosquito net }\end{array}$} \\
\hline & $\begin{array}{l}\text { Used } \\
\text { n }(\%)\end{array}$ & $\begin{array}{l}\text { Not } \\
\text { used } \\
\text { n (\%) }\end{array}$ & $\begin{array}{l}\text { Used } \\
\text { n }(\%)\end{array}$ & $\begin{array}{l}\text { Not used } \\
\text { n }(\%)\end{array}$ \\
\hline \multicolumn{5}{|l|}{ Respondent's age (years) } \\
\hline$<21$ years & $4(40.0)$ & $6(60.0)$ & $2(20.0)$ & $8(80.0)$ \\
\hline $21-60$ years & $\begin{array}{l}49 \\
(43.4)\end{array}$ & $\begin{array}{l}64 \\
(56.6)\end{array}$ & $\begin{array}{l}63 \\
(55.8)\end{array}$ & $50(44.2)$ \\
\hline$>60$ years & $\begin{array}{l}14 \\
(58.3)\end{array}$ & $\begin{array}{l}10 \\
(41.7)\end{array}$ & $\begin{array}{l}19 \\
(79.2)\end{array}$ & $5(20.8)$ \\
\hline$*_{\mathrm{p}}$ value & 0.382 & & $0.005^{*}$ & \\
\hline \multicolumn{5}{|l|}{ Gender } \\
\hline Male & $\begin{array}{l}21 \\
(36.8)\end{array}$ & $\begin{array}{l}36 \\
(63.2)\end{array}$ & $\begin{array}{l}27 \\
(47.4)\end{array}$ & $30(52.6)$ \\
\hline Female & $\begin{array}{l}46 \\
(51.1)\end{array}$ & $\begin{array}{l}44 \\
(48.9)\end{array}$ & $\begin{array}{l}57 \\
(63.3)\end{array}$ & $33(36.7)$ \\
\hline$* \mathrm{p}$ value & 0.091 & & 0.057 & \\
\hline \multicolumn{5}{|l|}{ Education level } \\
\hline Elementary school & $\begin{array}{l}56 \\
(59.6)\end{array}$ & $\begin{array}{l}38 \\
(40.4)\end{array}$ & $\begin{array}{l}66 \\
(70.2)\end{array}$ & $28(29.8)$ \\
\hline Junior high school & $8(20.0)$ & $\begin{array}{l}32 \\
(80.0)\end{array}$ & $\begin{array}{l}15 \\
(37.5)\end{array}$ & $25(62.5)$ \\
\hline Senior high school & $2(18.2)$ & $9(81.8)$ & $2(18.2)$ & $9(81.8)$ \\
\hline Higher education & $1(50.0)$ & $1(50.0)$ & $1(50.0)$ & $1(50.0)$ \\
\hline$* p$ value & $<0.001 *$ & & $<0.001 *$ & \\
\hline \multicolumn{5}{|l|}{ Occupation } \\
\hline Farmer & $\begin{array}{l}32 \\
(55.2)\end{array}$ & $\begin{array}{l}26 \\
(44.8)\end{array}$ & $\begin{array}{l}35 \\
(60.3)\end{array}$ & $23(39.7)$ \\
\hline Household mother & $\begin{array}{l}22 \\
(50.0)\end{array}$ & $\begin{array}{l}22 \\
(50.0)\end{array}$ & $\begin{array}{l}33 \\
(75.0)\end{array}$ & $11(25.0)$ \\
\hline Employers & $3(15.0)$ & $\begin{array}{l}17 \\
(85.0)\end{array}$ & $8(40.0)$ & $12(60.0)$ \\
\hline Employee & $\begin{array}{l}10 \\
(40.0)\end{array}$ & $\begin{array}{l}15 \\
(60.0)\end{array}$ & $8(32.0)$ & $17(68.0)$ \\
\hline${ }^{*} \mathrm{p}$ value & $0.016^{*}$ & & $0.002 *$ & \\
\hline
\end{tabular}




\section{QANUN MEDIKA Vol 5 No 1 JANUARY 2021}

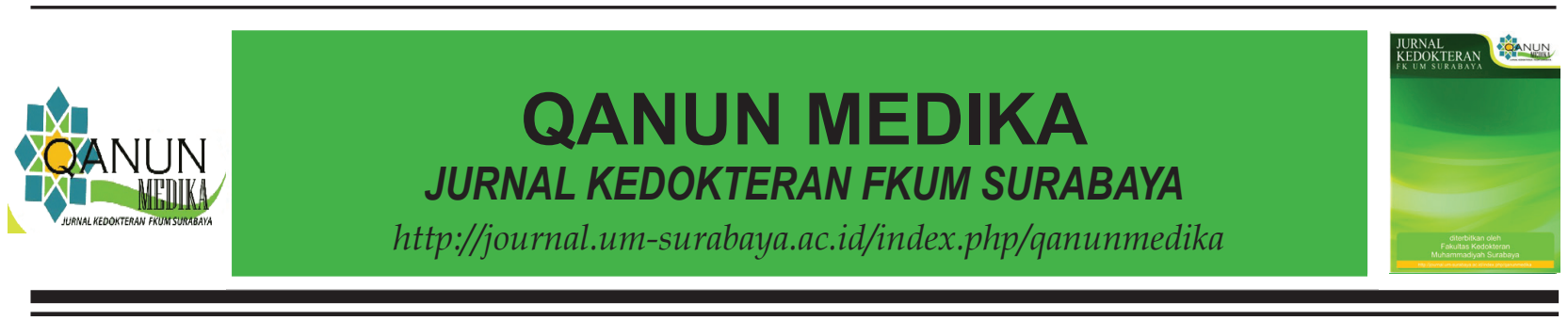

\begin{tabular}{|c|c|c|c|c|}
\hline \multicolumn{5}{|l|}{$\begin{array}{l}\text { Number of family } \\
\text { member }\end{array}$} \\
\hline $1-2$ family members & $\begin{array}{l}10 \\
(58.8)\end{array}$ & $7(41.2)$ & $\begin{array}{l}12 \\
(70.6)\end{array}$ & $5(29.4)$ \\
\hline 3-4 family members & $\begin{array}{l}35 \\
(41.7)\end{array}$ & $\begin{array}{l}49 \\
(58.3)\end{array}$ & $\begin{array}{l}44 \\
(52.4)\end{array}$ & $40(47.6)$ \\
\hline$>4$ family members & $\begin{array}{l}22 \\
(47.8)\end{array}$ & $\begin{array}{l}24 \\
(52.2)\end{array}$ & $\begin{array}{l}28 \\
(60.9)\end{array}$ & $18(39.1)$ \\
\hline$*$ p-value & 0.404 & & 0.318 & \\
\hline \multicolumn{5}{|l|}{$\begin{array}{l}\text { Attitude toward malaria } \\
\text { disease }\end{array}$} \\
\hline Good & $\begin{array}{l}34 \\
(59.6)\end{array}$ & $\begin{array}{l}23 \\
(40.4)\end{array}$ & $\begin{array}{l}42 \\
(73.7)\end{array}$ & $15(26.3)$ \\
\hline Poor & $\begin{array}{l}33 \\
(36.7)\end{array}$ & $\begin{array}{l}57 \\
(63.3)\end{array}$ & $\begin{array}{l}42 \\
(46.7)\end{array}$ & $48(53.3)$ \\
\hline$*_{\mathrm{p} \text {-value }}$ & $0.006^{*}$ & & $0.001 *$ & \\
\hline
\end{tabular}

Table 3 depicted a crude association between demographical and attitude factors with the practice of malaria prevention among respondents in rural areas. Among 147 respondents, the Chi-square analyses demonstrated that the percentage of using bed and ventilation mosquito net was very low, especially age $<21$ years old. In using bed and ventilation mosquito net, men were less likely compared to women. Education was significantly associated with the practice of malaria prevention $(\mathrm{p}<0.05)$. There was a statistically significant association between occupation and good attitude with practice. There was a statistically significant association between age and the used of ventilation mosquito net for malaria prevention $(\mathrm{p}=0.005)$.

\section{DISCUSSION}

The Indonesian Government delivered some elimination programs through an integrated approach which targeted in 2030 (Indonesia, 2016; Sitohang et al., 2018). This comprehensive solution involves the continuous distribution of insecticidetreated bed nets in highly resistant districts every two years, the distribution of Artemisinin Combination Therapy (ACT), and Residual Spray Insecticide (Hasyim, Dale, Groneberg, Kuch, \& Müller, 2019; Ipa et al., 2020; Setiyaningsih, Trapsilowati, Mujiyono, \& Lasmiati, 2018; Sitohang et al., 2018). Purworejo, Central Java, Indonesia, is considered a malaria-endemic area with the highest cases in 2015. Nowadays, Purworejo is categorized as a malaria low endemic area with stable incidence (Setiyaningsih et al., 2018; Sitohang et al., 2018). Our study analyzed with a questionnaire developed by researchers to describe the association between demographic and attitude factors with the practice of malaria prevention among the rural community. In general, our study reveals that education level, age groups, occupation, and attitude factors were associated significantly with the use of ventilation mosquito net for malaria prevention practice.

In this study, we identified that age and use of ventilation mosquito net for malaria prevention was stated as statistically significant. The use of bed and ventilation mosquito net constitutively $49 \%$ and $63 \%$ in age between 21 to 60 years were much higher than other groups. This may be due to the well-ordered distribution of bed nets and can also reach many villages, especially those with a history of high malaria 
cases locally (Setiyaningsih et al., 2018). This is also in line with other studies (Hetzel et al., 2012; Liu et al., 2015) even though the ITN/ LLIN usage rate is the lowest $(70.5 \%)$ in adult men $(\geq 15$ years) because men often go to the forest and return to their village. They may carry malaria from the forest to their community. Other studies also support this result that malaria is more common in the economically active age population (Tadesse, Fogarty, \& Deressa, 2018). Meanwhile, another study shows that age was associated with positive malaria test results (Tadesse et al., 2018). This contrasts with a study in 357 households where age, education level, and occupation were not significantly related to the use of insecticidetreated bed nets, but for household occupants who had LLIN, $74.7 \%$ of individuals over the age of 18 use their LLIN (Sanjana et al., 2006). According to previous research conducted in North West Ethiopia, it was found that sociodemographic factors such as age, educational status, gender, occupation, and religion were not statistically significant with malaria prevention (Alelign \& Petros, 2018). In addition, religion, occupation, and age group did not significantly affect attitudes to malaria prevention (Assan, Takian, Hanafi-Bojd, Rahimiforoushani, \& Nematolahi, 2017).

Meanwhile, respondents with a good attitude towards malaria prevention have a higher percentage of used bed and ventilation mosquito nets than respondents with a poor attitude. The attitude toward malaria prevention has a statistically significant association with the use of both bed and ventilation mosquito nets for malaria prevention $(\mathrm{p}=0.006$ and $\mathrm{p}=0.001$, respectively). In this research, attitude can be categorized into two categories, namely poor attitude (less than 80\%: $7-23$ scores) and a good attitude (80-100\%:24 - 28 scores) for analytical purposes (Bloom, 1956). Researchers find out the risk, prevention, and treatment of malaria by using the attitude questionnaire section. The majority of respondents (61.2\%) have a good attitude towards malaria prevention, with the use of bed mosquito net (54.4\%). Good attitude is represented by belief in disease prevention behavior at the individual and household levels. Nearly $50 \%$ of participants used selfprotection against mosquito bites by installing a mosquito net. There was also a significant relationship between the use of bed nets and practice (Kumar, Rathi, Lal, Goel, \& care, 2018). Research in 5 provinces in Indonesia's eastern part shows about half of the total respondents indicated utilization ITNs (Ipa et al., 2020).

The health effects of using treated bed nets have been confirmed in a variety of transmission settings (Gamble, Ekwaru, Garner, \& Ter Kuile, 2007; Lengeler, 2004). The use of appropriate and effective mosquito nets can reduce transmission by up to 90 percent in the community and can reduce all causes of under-five mortality by 44 percent (Eisele, Larsen, \& Steketee, 2010). One of the factors contributing to this success was the relatively low cost, ease of use, and flexibility of distribution (WHO, 2010). Most respondents did not use a ventilation mosquito net (57.1\%). Other studies have determined various factors in various settings, the most common of which are users complaining that they are too hot under the network, few mosquitoes around or malaria is not a severe problem, ITN is no longer effective, ITN is in bad condition, ITN is being stored. It can be said difficulties of laying nets in traditional houses and lack of adequate space under the network for all household members (Batega, 2004; Baume, Reithinger, \& Woldehanna, 2009). Efforts to increase the use of bed nets should focus on clear local evidence of why people use or do not use bed nets. There is, however, a lack of dedicated and well-designed research on the reasons for not using nets, as indicated by a recently 


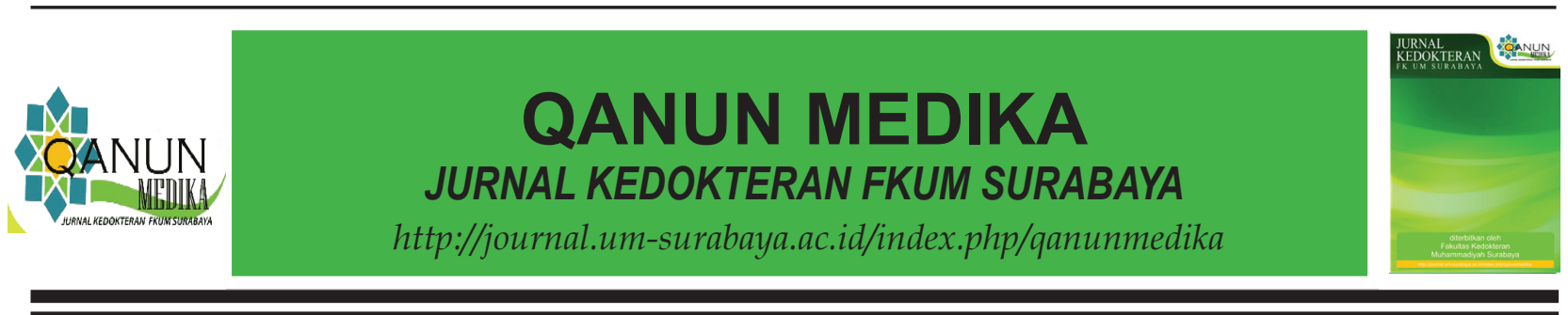

published literature review. Tentatively, this analysis found that heat-related discomfort and absence of mosquitoes were frequently reported as reasons for disuse, whereas in this survey, these reasons were stated less frequently. Some clearly value the mosquito net as a valuable household asset (sometimes belonging to certain individuals) even though it is used for defense against mosquitoes that transmit malaria (Pulford, Hetzel, Bryant, Siba, \& Mueller, 2011). It is also possible by geographic area in Purworejo that the insufficient (and somewhat heterogeneous) supply of bed nets could be due to the entire distribution system's many factors. Village accessibility has been described as the primary determinant of net ownership (Hetzel et al., 2012). Contrary to other studies in Ratanakiri Province, Cambodia found a very high percentage of mosquito nets use. The results showed that $95.8 \%$ of respondents used a mosquito net at home, $83.8 \%$ used long-sleeved clothing for malaria prevention (Yasuoka et al., 2018). Other studies showed that most of the respondents $(95.8 \%)$ thought that malaria was a preventable and curable disease.

The percentage of using bed and ventilation mosquito net was high among respondents who graduated from elementary school compare to other education levels. Education levels were significantly associated with the use of both bed and ventilation mosquito nets $(p<0.001)$. This study also in line with another study in Myanmar and Kenya (N Ng'ang'a et al., 2009). Another study for bivariate analysis shows any significant correlation between education and malaria knowledge, even though 53.3\% participants graduate from elementary school (Trapsilowati, Pujiyanti, \& Wigati, 2018). The bed net use is also associated with adequate knowledge about malaria transmission and parent's perception of bed nets (Eisele et al., 2009; Noor, Kirui, Brooker, \& Snow, 2009;
Noor, Omumbo, Amin, Zurovac, \& Snow, 2006; Ordinioha, 2007). It is maybe because, in recent years, primary and secondary schools have concentrated on disease prevention and sanitation education, including bed net use in the district where the villages surveyed in this study are located. This systematic educational program may explain the high prevalence of nets in these villages, although respondents only graduated from elementary school program (Ndjinga \& Minakawa, 2010). It is contradictory to other studies that respondents need more years of education to use a bed net (García-Basteiro et al., 2011; Yitayew, Enyew, Goshu, \& Treatment, 2018).

The occupation was significantly associated with the practice of using both bed and ventilation mosquito nets for malaria prevention ( $p=0.016$ and $p=0.002$, respectively). The highest percentage of using both bed and ventilation mosquito nets were a farmer and household mother. It was about 55.2 and $50 \%$ of using bed mosquito net for the farmer and household mother, and about 60.3 and $75 \%$ of using ventilation mosquito net for the farmer and household mother. The majority of participants who were engaged in farming also correlated with another study (Ipa et al., 2020; Liu et al., 2015). Several authors have highlighted that households' socioeconomic status affects bed net usage and is the most important determinant of net use. More wealthy families are much more likely to use nets (Hetzel et al., 2012; Koenker \& Kilian, 2014; Xu, Liao, Liu, Nie, \& Havumaki, 2014). This could be explained by the fact that farmers and household mothers also reach from malaria message with radio, newspaper, internet, television, and other print media by a well-promoting malaria elimination program from Purworejo, district health office. Household mothers possibly have more time to learn information during their home activity, it will help to understand all about the malaria prevention program. This program has started to develop and expanded since 2008. The control 
of malaria vectors that have been carried out in the Purworejo region includes insecticidetreated mosquito nets and house spraying with insecticides (Indoor Residual Spraying / IRS). Malaria prevention is also carried out through patient care and adequate treatment and preventive medication for pregnant women (B2P2VRP, 2015; Indonesia, 2016; Talipouo et al., 2019). In order to increase the community's knowledge and understanding of malaria and its preventive action, additional sensitization resources such as community educators, focus group discussions, or social media (Facebook, WhatsApp, YouTube), which are now commonly used by the public, should be used. However, the use of social media to educate the population at the national level is still not common and maybe a good way to communicate with the population (Arroz et al., 2019)

\section{CONCLUSION}

The practice of malaria prevention among respondents in Purworejo District of Indonesia was very low. Education level, type of occupation, and attitude towards malaria prevention were associated with both bed and ventilation mosquito used. Improving malaria prevention by increasing awareness of communities for using bed and ventilation nets is needed to decrease morbidity and mortality due to malaria.

\section{REFERENCES}

Alelign, A., \& Petros, B. (2018). Knowledge, attitudes and practices of malaria transmission and preventive measures in Woreta town, Northwest Ethiopia. BMC, 11(1), 491.

Arroz, J. A., Candrinho, B. N., Mussambala, F., Chande, M., Mendis, C., Dias, S., \& Maria do Rosario, O. M. J. B. h. s. r.
(2019). WhatsApp: a supplementary tool for improving bed nets universal coverage campaign in Mozambique. BMC Health Services Research, 19(1), 1-7.

Asante, F. A., \& Asenso-Okyere, K. (2003). Economic burden of malaria in Ghana. $A$ Technical Report Submitted to the World Health Organisation (WHO), African Regional Office (AFRO)., 1-81.

Assan, A., Takian, A., Hanafi-Bojd, A. A., Rahimiforoushani, A., \& Nematolahi, S. J. J. o. P. H. P. (2017). Knowledge, attitude, and practice about malaria: Socio-demographic implications for malaria control in rural Ghana. $J$ Public Health Policy, 38(4), 445-463. doi: 10.1057/s41271-017-0088-6

B2P2VRP. (2015). Laporan rikhus vektora Propinsi Jawa Tengah, salatiga.

Bachou, H., Tylleskär, T., Kaddu-Mulindwa, D. H., \& Tumwine, J. K. J. B. i. d. (2006). Bacteraemia among severely malnourished children infected and uninfected with the human immunodeficiency virus-1 in Kampala, Uganda. BMC Infectious Disease, 6(1), 160.

Batega, D. W. (2004). Knowledge attitudes and practices about malaria treatment and prevention in Uganda. Final Report prepared for Ministry of Health in part of Health Communication Partnership based at Johns Hopkins Bloomberg School of Public Health/Center for Communication Programs.

Baume, C. A., Reithinger, R., \& Woldehanna, S. J. M. J. (2009). Factors associated with use and non-use of mosquito nets owned in Oromia and Amhara regional states, Ethiopia. Malaria Journal, 8(1), 264. 
Bhatt, S., Weiss, D., Cameron, E., Bisanzio, D., Mappin, B., Dalrymple, U., . . . Eckhoff, P. J. N. (2015). The effect of malaria control on Plasmodium falciparum in Africa between 2000 and 2015. Nature, 526(7572), 207-211.

Bloom, B. S. J. N. Y. M. (1956). Taxonomy of educational objectives. Vol. 1: Cognitive domain. 20, 24.

Dinas Kesehatan Purworejo. (2019). Laporan Bulanan Malaria Dinkes Kabupaten Purworejo.

Eisele, T. P., Keating, J., Littrell, M., Larsen, D., Macintyre, K. J. T. A. j. o. t. m., \& hygiene. (2009). Assessment of insecticide-treated bednet use among children and pregnant women across 15 countries using standardized national surveys. Am J Trop Med Hyg, 80(2), 209-214.

Eisele, T. P., Larsen, D., \& Steketee, R. W. J. I. j. o. e. (2010). Protective efficacy of interventions for preventing malaria mortality in children in Plasmodium falciparum endemic areas. International Journalof Epidemiology, 39(suppl_1), i88-i101.

Gamble, C., Ekwaru, P. J., Garner, P., \& Ter Kuile, F. O. J. P. M. (2007). Insecticidetreated nets for the prevention of malaria in pregnancy: a systematic review of randomised controlled trials. PLoS Med 4(3):e107. doi:10.1371/journal. pmed.0040107

García-Basteiro, A. L., Schwabe, C., Aragon, C., Baltazar, G., Rehman, A. M., Matias, A., . . . Kleinschmidt, I. J. M. j. (2011). Determinants of bed net use in children under five and household bed net ownership on Bioko Island, Equatorial Guinea. Malaria Journal, 10(1), 179.
Hasyim, H., Dale, P., Groneberg, D. A., Kuch, U., \& Müller, R. (2019). Social determinants of malaria in an endemic area of Indonesia. Malaria Journal, 18(1), 134.

Hetzel, M. W., Gideon, G., Lote, N., Makita, L., Siba, P. M., \& Mueller, I. J. M. j. (2012). Ownership and usage of mosquito nets after four years of large-scale free distribution in Papua New Guinea. Malaria Journal, 11(1), 192.

Iliyasu, Z., Babashani, M., Abubakar, I. S., Salahudeen, A. A., \& Aliyu, M. H. J. A. t. (2013). Clinical burden and correlates of HIV and malaria co-infection, in northwest Nigeria. Acta Tropica, 128(3), 630-635.

Indonesia, M. (2016). The desk review malaria programe review 2016. 1-74.

Ipa, M., Widawati, M., Laksono, A. D., Kusrini, I., \& Dhewantara, P. W. J. P. O. (2020). Variation of preventive practices and its association with malaria infection in eastern Indonesia: Findings from community-based survey. Plos One Journal, 15(5), e0232909.

Kementrian Kesehatan RI. (2009). SK no 293/ MENKES/SK/IV/2009.

Kementrian Kesehatan RI. (2017). Buku Saku Menuju Eliminasi Malaria. Jakarta : Ministry of Health. 1-30.

Kementrian Kesehatan RI. (2020). Situasi Malaria di Indonesia Tahun 2019.

Koenker, H., \& Kilian, A. J. P. O. (2014). Recalculating the net use gap: a multicountry comparison of ITN use versus ITN access. Plos One Journal, 9(5), e97496.

Kumar, V., Rathi, A., Lal, P., Goel, S. K. J. J. o. f. m., \& care, p. (2018). Malaria and dengue: Knowledge, attitude, practice, and effect 
of sensitization workshop among school teachers as health educators. Journal of Familly Medicine and Primary Care, 7(6), 1368.

Lengeler, C. J. C. d. o. s. r. (2004). Insecticidetreated bed nets and curtains for preventing malaria. Cochrane (2). doi:https://doi. org/10.1002/14651858.CD000363.pub2

Liu, H., Xu, J.-w., Guo, X.-r., Havumaki, J., Lin, Y.-X., Yu, G.-c., \& Zhou, D.-1. J. M. j. (2015). Coverage, use and maintenance of bed nets and related influence factors in Kachin Special Region II, northeastern Myanmar. Malaria Journal, 14(1), 212.

Lover, A. A., Sutton, B. A., Asy, A. J., \& WilderSmith, A. J. M. j. (2011). An exploratory study of treated-bed nets in Timor-Leste: patterns of intended and alternative usage. Malaria Journal, 10(1), 199.

Masum, H., Shah, R., Schroeder, K., Daar, A. S., Singer, P. A. J. B. i. h., \& rights, h. (2010). Africa's largest long-lasting insecticidetreated net producer: lessons from $\mathrm{A}$ to $\mathrm{Z}$ Textiles. BMC International Health and Human Rights, 10(1), 1-6.

Monasch, R., Reinisch, A., Steketee, R. W., Korenromp, E. L., Alnwick, D., Bergevin, Y. J. T. A. j. o. t. m., \& hygiene. (2004). Child coverage with mosquito nets and malaria treatment from population-based surveys in African countries: a baseline for monitoring progress in roll back malaria. Am J Trop Med Hyg, 71(2_suppl), 232238.

Murhandarwati, E. E. H., Fuad, A., Wijayanti, M. A., Bia, M. B., Widartono, B. S., Lobo, N. F., \& Hawley, W. A. J. M. j. (2015). Change of strategy is required for malaria elimination: a case study in Purworejo District, Central Java Province, Indonesia. Malaria Journal, 14(1), 318.
Mursid, R., Sudibyakto, H., Gunawan, T., Sutomo, A., \& Windraswara, R. (2015). Global and micro climate change related to the dynamics of Anopheles sp. in malaria-endemic area Purworejo City, Central Java. International Journal Science Basic Research, 22(1).

N Ng'ang'a, P., Jayasinghe, G., Kimani, V., Shililu, J., Kabutha, C., Kabuage, L., . . . Mutero, C. J. M. j. (2009). Bed net use and associated factors in a rice farming community in Central Kenya. Malaria Journal, 8(1), 1-8.

Ndjinga, J. K., \& Minakawa, N. J. M. j. (2010). The importance of education to increase the use of bed nets in villages outside of Kinshasa, Democratic Republic of the Congo. Malaria Journal, 9(1), 279.

Noor, A. M., Kirui, V. C., Brooker, S. J., \& Snow, R. W. J. B. P. H. (2009). The use of insecticide treated nets by age: implications for universal coverage in Africa. BMC Public Health, 9(1), 369.

Noor, A. M., Omumbo, J. A., Amin, A. A., Zurovac, D., \& Snow, R. W. (2006). Wealth, mother's education and physical access as determinants of retail sector net use in rural Kenya. Malaria Journal, $5(1), 5$.

Ordinioha, B. (2007). The use of insecticidetreated bed net in a semi-urban community in south-south, Nigeria. Niger $J$ Med, 16(3), 223-226.

Pinchoff, J., Hamapumbu, H., Kobayashi, T., Simubali, L., Stevenson, J. C., Norris, D. E., . . . hygiene. (2015). Factors associated with sustained use of longlasting insecticide-treated nets following a reduction in malaria transmission in southern Zambia. Am. J. Trop. Med. Hyg, 93(5), 954-960. 


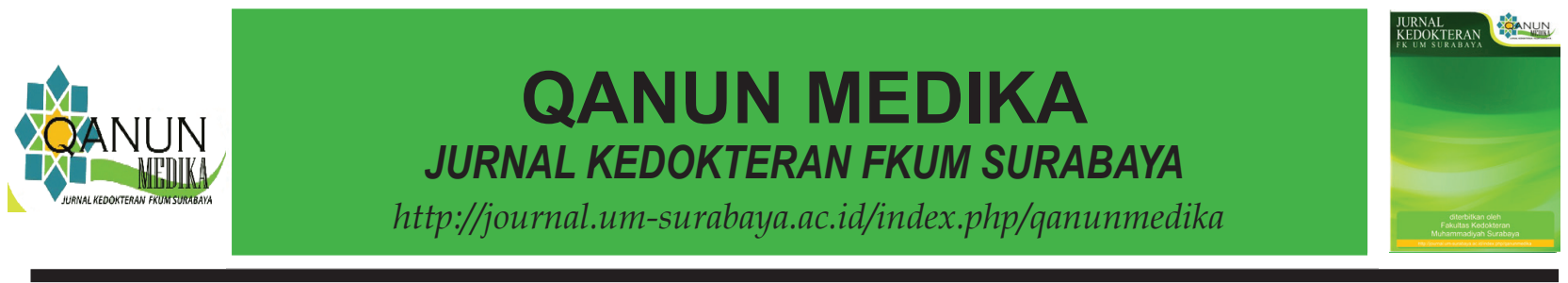

Pulford, J., Hetzel, M. W., Bryant, M., Siba, P. M., \& Mueller, I. J. M.j. (2011). Reported reasons for not using a mosquito net when one is available: a review of the published literature. Malaria Journal, 10(1), 83.

Rejeki, D. S. S., Fuad, A., Widartono, B. S., Murhandarwati, E. E. H., \& Kusnanto, H. J. M. j. (2019). Spatiotemporal patterns of malaria at cross-boundaries area in Menoreh Hills, Java, Indonesia. Malaria Journal 18(1), 80.

Sanjana, P., Barcus, M. J., Bangs, M. J., Ompusunggu, S., Elyazar, I., Marwoto, H., . . . hygiene. (2006). Survey of community knowledge, attitudes, and practices during a malaria epidemic in central Java, Indonesia. Am. J. Trop. Med. Hyg., 75(5), 783-789.

Setiyaningsih, R., Trapsilowati, W., Mujiyono, M., \& Lasmiati, L. (2018). Pengendalian Vektor Malaria di Daerah Endemis Kabupaten Purworejo, Indonesia. Balaba: Jurnal Litbang Pengendalian Penyakit Bersumber Binatang Banjarnegara, 1-12.

Sitohang, V., Sariwati, E., Fajariyani, S. B., Hwang, D., Kurnia, B., Hapsari, R. K., . . . Hawley, W. A. J. M. j. (2018). Malaria elimination in Indonesia: halfway there. The Lancet Global Health, 6(6), e604-e606.

Tadesse, F., Fogarty, A. W., \& Deressa, W. (2018). Prevalence and associated risk factors of malaria among adults in East Shewa Zone of Oromia Regional State, Ethiopia: a cross-sectional study. $B M C$ Public Health, 18(1), 25.

Talipouo, A., Ngadjeu, C. S., Doumbe-Belisse, P., Djamouko-Djonkam, L., Sonhafouo-
Chiana, N., Kopya, E., . . . Kekeunou, S. J. M. j. (2019). Malaria prevention in the city of Yaoundé: knowledge and practices of urban dwellers. Malaria Journal, 18(1), 167.

Trapsilowati, W., Pujiyanti, A., \& Wigati, W. (2018). Gambaran Pengetahuan, Sikap dan Tindakan Masyarakat pada Peningkatan Kasus Malaria di Kabupaten Purworejo Tahun 2015. J Aspirator, 10(1), 9-14.

WHO. (2010). World Malaria Report 2009.

WHO. (2016). World malaria report 2015: World Health Organization.

WHO. (2018). World Malaria Report 2018. Geneva: World Health Organization. 3, $1-210$.

WHO. (2019). World Malaria Report: 2019. (1), 1-232.

Xu, J.-w., Liao, Y.-m., Liu, H., Nie, R.-h., \& Havumaki, J. J. P. O. (2014). Use of bed nets and factors that influence bed net use among Jinuo ethnic minority in Southern China. Plos One Journal, 9(7), e103780.

Yasuoka, J., Kikuchi, K., Nanishi, K., Ly, P., Thavrin, B., Omatsu, T., \& Mizutani, T. J. B. p. h. (2018). Malaria knowledge, preventive actions, and treatmentseeking behavior among ethnic minorities in Ratanakiri Province, Cambodia: a community-based cross-sectional survey. BMC Public Health, 18(1), 1206.

Yitayew, A. E., Enyew, H. D., Goshu, Y. A. J. M. R., \& Treatment. (2018). Utilization and Associated Factors of Insecticide Treated Bed Net among Pregnant Women Attending Antenatal Clinic of Addis Zemen Hospital, North-Western Ethiopia: An Institutional Based Study. Hindawi Malaria Research and Treatment, 2018. 